\title{
Variations in the number of genital setae in Raphignathus hecmatanensis species (Acari: Raphignathidae)
}

\author{
Mustafa AKYOL \\ Manisa Celal Bayar University, Faculty of Arts and Sciences, Department of Biology, Manisa, TURKEY \\ makyol77@gmail.com
}

Received Date: 10.04.2017

Accepted Date: 10.04 .2018

\section{Abstract}

Aim of study: In this study, in 32 females species of the Raphignathus hecmatanaensis Khanjani and Ueckermann, 2003, were found from the samples collected from different of the same date and localities, variations in genital setae numbers were determined in 10 species.

Area of study: This study was conducted at the Zoology Research Laboratory, Department of Biology Faculty of Arts and Sciences, Manisa Celal Bayar University. The soil and litter samples were found from Emirdağları, $1300 \mathrm{~m}$ a.s.l., Büyükkarabağ village, Bolvadin district, Afyonkarahisar, Turkey.

Material and Methods: Soil samples and litter taken from under Crataegus sp., Astragalus sp., Euphorbia sp., Rosacanina sp. in research area were brought to the laboratory in PVC bags and extracted in Berlese funnels for 7 days. Mites accumulating in collection bottles with $70 \%$ alcohol, were selected from the samples under a stereomicroscope, left to clear into lactophenol and then embedded in Hoyer's solution. 32 females species of the $R$. hecmatanaensis were determined and examined.

Main results: In Turkish (Afyonkarahisar) specimens, $R$. hecmatanaensis in 32 females, while 22 females have 6 genital setae ( 3 pairs), 9 females have abnormal 7 genital setae and one female have abnormal 5 genital setae.

Research highlights: It is very interesting, about one-third of the $R$. hecmatanaensis species have been found to have an abnormal number of genital setae. In this case, genital setae number used for key to the species of Raphignathus is debate.

Keywords: Acari, Raphignathus hecmatanensis, variation, genital setae.

\section{Raphignathus hecmatanensis (Acari: Raphignathidae) türünde görülen genital kıl sayısındaki varyasyonlar}

Özet

Çalışmanın amacı: Bu çalışmada, aynı lokalite ve tarihte farklı habitatlardan (Crataegus sp., Astragalus sp., Euphorbia sp. ve Rosacanina sp. altı toprak ve döküntü örneği) toplanan örneklerden tespit edilen Raphignathus hecmatanaensis Khanjani ve Ueckermann, 2003 türüne ait 32 dişi akar örneğin 10 dişi bireyinde genital bölgesindeki kıl sayılarında varyasyonlar verilmiştir.

Çalışma alanı: Bu çalışma, Biyoloji Bölümü, Fen Edebiyat Fakültesi, Manisa Celal Bayar Üniversitesi, Zooloji Araştırma Laboratuvarında yürütülmüş, döküntü ve toprak örnekleri Afyonkarahisar ili, Bolvadin ilçesi, Büyükkarabağ köyü, Emirdağları, 1300 m'den toplanmıştır.

Materyal ve Yöntem: Toprak ve döküntü örnekleri çalışma alanında Crataegus sp., Astragalus sp., Euphorbia sp. ve Rosacanina sp. altından alınıp PVC torbalar içerisinde laboratuvara getirilmiștir. Berlese hunilerinde bir hafta, \% 70'lik alkol bulunan şişelerinde biriken akarlar, stereo mikroskop altında ayıklanıp, laktofenol içerisine bırakılmış ve daha sonra Hoyer ortamında preparatları yapılmıştır. 32 dişi $R$. hecmatanaensis türü tespit edilmiş ve incelenmiştir.

Temel Sonuçlar: R. hecmatanaensis Türkiye (Afyonkarahisar) türüne ait 32 dişi akar örneğin 10 dişi bireyinde genital bölgesindeki kıl sayılarında varyasyonlar verilmiştir. 32 dişi bireyin, 22 dişi bireyde normal olarak genital kıl sayısı 3 çift olmak üzere 6 kıl iken; dokuzunda anormal olarak genital kıl sayısı 7, birinde anormal olarak genital kıl sayısı 5 olarak tespit edilmiştir.

Araştırma vurgulart: Çalışmamızda $R$. hecmatanaensis türünün üçte birinde genital kıl sayısında varyasyonlar bulunmuştur. Bu duruma göre Raphignathus cinslerine ait tür tayin anahtarında genital kıl sayılarının kullanılması tartışmalıdır.

Anahtar kelimeler: Acari, Raphignathus hecmatanaensis, varyasyon, genital k1l.

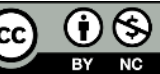




\section{Introduction}

Raphignathidae is older family than the other 11 families in superfamily Raphignathoidea. They are predatory mites and can be found different habitat (in litter and soil, moss, lichens, warehouse products, house dust, birds nests, intestine and the urine of a human) (Atyeo et al. 1961, Atyeo 1963, Doğan 2003, Fan and Yin 2000, Khanjani and Ueckermann 2003, Meyer and Ueckermann 1989, Zaher and Gomaa 1979). They are distinguished by the cervical peritremes not led in dorsal upper of stylophore and converging coxae (Meyer and Ueckermann 1989). This family with 2 genera (Raphignathus Dugés and Neoraphignathus Smiley and Moser). The genus Raphignathus is known in all zoogeography region, and represented by more than 63 species (Bagheri et al. 2013). It is known 22 species in Turkey in this genus. (Koç and Ayyıldız 1996, Doğan 2003, Doğan and Ayyıldız 2003, Koç and Akyol 2004, Koç and Kara 2005, Akyol, and Koç 2006a, b, 2007, 2010, Dönel and Doğan 2011, 2013).

Raphignathus species having 3 or 4 pairs of genital setae. Genital setae number was used by Khanjani and Ueckermann in key to the species of Raphignathus. In orginal description, Raphignathus hecmatanaensis Khanjani and Ueckermann having 3 pairs genital setae. In 8 females species of the $R$. hecmatanaensis, only one specimen having 4 setae on one side and 3 setae other side of genital opening, was reported by Khanjani and Ueckermann (Khanjani and Ueckermann 2003).

In this study, in 32 females species of the $R$. hecmatanaensis living in soil samples collected from Afyonkarahisar province, variations in genital setae numbers were determined in 10 females species. It is very interesting, about one-third of the $R$. hecmatanaensis species have been found to have an abnormal number of genital setae. In this case, genital setae number used for key to the species of Raphignathus is debate. Also a Turkish (Afyonkarahisar) specimen $R$. hecmatanaensis is re-descripted and abnormal genital setae some of genital shields are illustrated.

\section{Material and methods}

Soil samples and litter taken from under Crataegus sp., Astragalus sp., Euphorbia sp., Rosacanina sp. in research area were brought to the laboratory in PVC bags and extracted in Berlese funnels for 7 days. Mites accumulating in collection bottles with $70 \%$ alcohol, were selected from the samples under a stereomicroscope, left to clear into lactophenol and then mounted on slides in Hoyer's solution.

Leg and dorsal designations pursue Grandjean (1944) and Kethley (1990), in order of. All of them measurements are micrometres $(\mu \mathrm{m}) .32$ females species of the Raphignathus hecmatanaensis Khanjani and Ueckermann were determined and examined. Type material and other specimens are stored in the Zoological Laboratory of Manisa Celal Bayar University, Manisa, Turkey.

\section{Results and Discussion \\ Raphignathus Dugés, 1834}

Type species: Raphignathus ruberrimus Dugés, 1834.

Propodosoma with one median and 2 lareral plates; opisthosoma with a wide plate; dorsum with 11-12 pairs of setae; one pair of eyes on lateral propodosomal plates; 2 pairs of aggenital setae, genital plate with 3 or 4 pairs of setae; anal plate with 3 pairs of setae; coxae I-IV adjoining; chelicerae form a conical stylophore; peritremes arising from midbasal part of stylophore, extending along anterior margin of idiosoma; palptibial claw small; subcapitulum with 2 pairs of adoral setae and 2 pairs of supcapitular setae.

Raphignathus hecmatanaensis Khanjani and Ueckermann, 2003

Female (Fig.1)

Length of body (including gnathosoma) (minimal - maximal measurements) 379 (330-392), width 168 (154-190).

Gnathosoma. Length of gnathosoma 97. Dorsal stylophore with striae. The tubular peritremes come out of the rear middle of the stylophore and each of the arms extends towards the sides of the propodosoma. Subcapitulum with 2 pairs of setae $(n=m=32)$ and 2 pairs of adoral setae $\left(a d_{1-2}\right)$. 
Palp setal formula ( Tarsus - femur ): $4+1 \omega+4$ eupathidia $-3+1$ claw $-2-2$.

Dorsum. All plates of dorsum dotted. Body surface striped between propodosomal and opisthosomal plates. Propodosoma with 2 lateral, one median, and 2 small plates behind median propodosomal plate. Opisthosoma with one plate. Median prodorsal plate narrow posteriorly and spherical anteriorly, with 3 pairs of setae. Each lateral prodorsal plates with 3 pairs of setae, one pair of eyes, and one pair of lyrifissures (ia). 2 pairs of setae, $\left(d_{1}\right),\left(e_{1}\right)$ and one pair of lyrifissures (im), located on interscutal membrane. Opisthosomal plate with 4 pairs of setae and one pair of lyrifissures (ip). Dorsal setae simple. Measurement and distances between of dorsal setae: $v i=30, s c i=30, v e=38$, sce $=32$, $c_{1}=27, c_{2}=27, d_{1}=30, e_{1}=27, f_{1}=27, h_{1}=27$, $h_{2}=27, \quad h_{3}=27 ; \quad v i-v i=24, \quad v i-s c i=32$, ve$v e=97, v e-s c i=27, s c i-s c i=46, v e-s c e=30$, sce-sce $=140$, sce- $c_{1}=84, c_{1}-c_{1}=16, c_{1}-c_{2}=46$, $c_{2}-c_{2}=108,, d_{1}-d_{1}=54, d_{1}-e_{1}=27, e_{1}-e_{1}=65, e_{1}-$ $f_{1}=24, \quad f_{1}-f_{1}=49, \quad f_{1}-h_{1}=32, \quad h_{1}-h_{1}=22, \quad h_{1}-$ $h_{2}=24, h_{2}-h_{2}=41, h_{3}-h_{3}=65$.

Venter. Venter striped, with 5 pairs setae $(1 a, 3 a, 4 a, 4 c, a g) ; \quad l a$ located on coxisternal plates which are between coxae I and II; $3 a$ on coxisternal plates, between coxae III and IV; $4 a$ on between coxae IV; $4 c$ and $a g$ on opisthosoma; genital plate with 3 pairs of genital setae $\left(g_{1-3}\right)$; one pair of lyrifissures $(\mathrm{ih})$ located laterally of genital plate; anal plate with 3 pairs of setae $\left(p s_{1-3}\right)$; coxisternal and genital plates dotted; Measurement of ventral setae: $1 a=35,3 a=$ 30, $4 a=4 c=22, a g=19, g_{1}=g_{2}=g_{3}=16$, $p s_{1}=p s_{2}=p s_{3}=19$.

Legs. Length of legs I-IV (femur - tarsal claw): 216-176-190-230. Count of setae on legs I-IV: tarsi 21( $\varphi \rho, \omega)-16(\omega)-14(\omega)-13$, tibiae $6(\varphi \rho)-6(\varphi \rho)-6(\varphi \rho)-5(\varphi \rho)$, genua $6(k)$ 6(k)-4-4, femora 6-5-3-3, trochanters 1-12-1, coxae 2-2-2-1.

Male: Not known yet.

Examined materials: 3 females and 5 abnormal fameles from litter under
Crataegus sp. and Rosacanina sp., 15 females and 4 abnormal fameles from litter under Astragalus sp., 4 females and one abnormal famele from litter under Euphorbia sp., Bolvadin district, Büyükkarabağ village, Emirdağları, $38^{\circ} 47^{\prime} 12^{\prime \prime} \mathrm{N}, 31^{\circ} 15^{\prime} 02^{\prime \prime} \mathrm{E}$, $1300 \mathrm{~m}$ a.s.1., 06.12.2009, Afyonkarahisar, Turkey, leg. M. Akyol.

Distribution: Iran (Khanjani and Ueckermann 2003) and Turkey: Kırıkkale, Denizli (Doğan and Ayyıldız 2003), Manisa (Koç and Akyol 2006b) and Afyonkarahisar (Akyol 2007).

Remarks: This species was defined from Iran on the basis of the famale that are found in the litter and soil from Sophora pachycarpa, Glycyrhiza glabra and soil covered with wheat (Khanjani and Ueckermann 2003). In Turkey (Kırıkkale, Denizli Manisa and Afyonkarahisar), it is found in very different habitats (Dogan and Ayyıldız 2003, Koç and Akyol 2006a, Akyol 2007). Iranian specimens length of body (including gnathosoma) was given as 356 (293-416)/ 198 (164-198) $\mu \mathrm{m}$ (Khanjani and Ueckermann 2003). Turkish (Afyonkarahisar) specimens length of body (including gnathosoma) was given as 379 (330-392) /168 (154-190) $\mu \mathrm{m}$. According to this, the Turkish (Afyonkarahisar) specimens are close to the Iranian specimens in terms of body size.

Type specimens with opisthosomal setae $h_{3}$ on small plates not separated from opisthosomal plate; but, all Turkish (Afyonkarahisar) specimens without setae $h_{3}$ on small plates. In Turkish (Afyonkarahisar) specimens, Raphignathus hecmatanaensis Khanjani and Ueckermann, 2003, in 32 females, while 22 females have 6 genital setae ( 3 pairs), 9 females have abnormal 7 genital setae and one female have abnormal 5 genital setae. It is very interesting, about one-third of the $R$. hecmatanaensis species have been found to have an abnormal number of genital setae. In Iran specimens, $R$. hecmatanaensis, in 8 females, only one species was reported that the number of genital setae abnormally 7 (Khanjani and Ueckermann 2003). In this case, genital setae 
number used for key to the species of Raphignathus is debate.

Turkish (Afyonkarahisar) specimens are similar to Iranian specimens in terms of their other structural features.

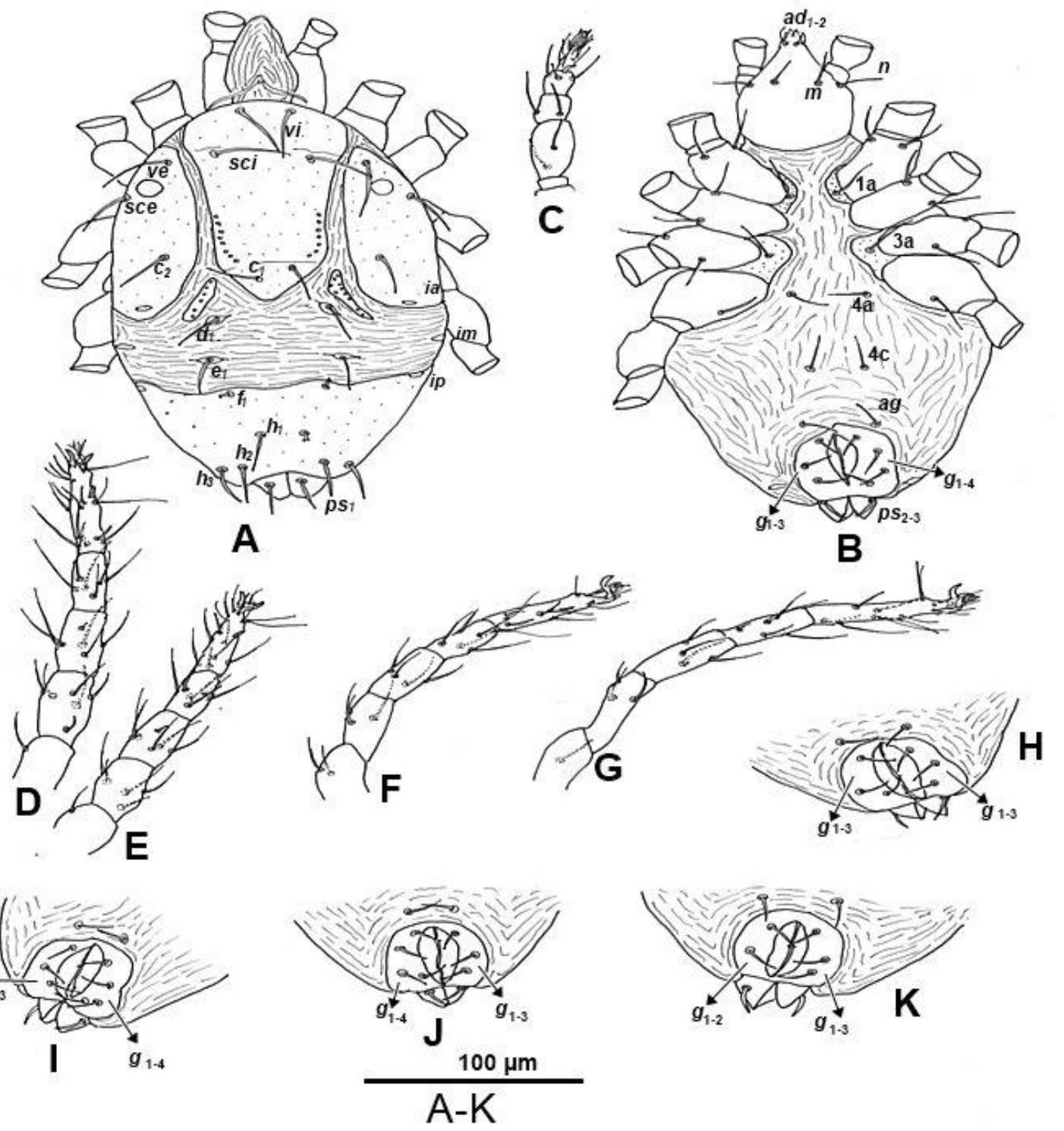

Figure 1. Raphignathus hecmatanaensis (Female). A) Dorsal image, B) Vetral image, C) Palpus, D) Leg I, E) Leg II, F) Leg III, G) Leg IV, H) Genital plate, 3 pairs of genital setae ( $g_{1-}$ 3), I) Abnormal genital setae, 3 on the right, 4 on the left, J) Abnormal genital setae, 4 on the right, 3 on the left, K) Abnormal genital setae, 2 on the right, 3 on the left.

\section{Acknowledgement}

This work was presented concisely as poster in the 22nd National Biology Congress, June 23-27, 2014, Eskişehir Osmangazi University, Eskişehir.

\section{References}

Akyol, M. (2007). Afyonkarahisar ili Raphignathoidea (Acari: Actinedida) üst familyasina ait taksonların sistematik yönden incelenmesi (Yayınlanmamış Doktora Tezi) Celal Bayar Üniversitesi, Fen Bilimleri Enstistüsü, Manisa. 
Akyol, M., Koç, K. (2006a). Raphignathus mites from Turkey (Acari: Raphignathidae). Journal of Natural History, 40(17-18), 1149-1165.

Akyol, M., Koç, K. (2006b). Türkiye faunası için üç yeni Raphignathus türü. XVIII. Ulusal Biyoloji Kongresi, Z1550, p. 276, Aydın.

Akyol, M., Koç, K. (2007). Two new records of the genus Raphignathus (Acari: Actinedida) for the Turkish Fauna. Nobel International Journals, 1(3), 1318.

Akyol, M., Koç, K. (2010). Contributions to the raphignathoid fauna of Turkey, with a description of a new species of Cryptognathus Kramer (Acari: Actinedida: Raphignathoidea). Turkish Journal of Zoology, 34, 159-167. doi:10.3906/zoo-0811-5.

Atyeo, WT. (1963). New and redescribed species of Raphignathidae (Acarina) and a discussion of the chaetotaxy of Raphignathoidea. Journal of the Kansas Entomological Society, 36(3), 172-186.

Atyeo, WT., Baker, EA., Crossley, DA. (1961). The genus Raphignathus Dugés (Acarina: Raphignathoidea) in the United State with notes on the Old World species. Acarologia, 3(1), 14-20.

Bagheri, M., Jafari, S., Saeej, PS. (2013). A new species of the genus Raphignathus Dugés (Acari: Raphignathidae) from western Iran. Persian Journal of Acarology, 2(3), 481-486.

Doğan, S. (2003). Descriptions of there new species and two new records of Raphignathus Dugés (Acari: Raphignathidae) from Turkey. Archives des Sciences, 56(3), 143-153.

Doğan, S., Ayyıldız, N. (2003). Mites of the genus Raphignathus (Acari: Raphignathidae) from Turkey. New Zealand Journal of Zoology, 30(2), 141148.

Dönel, G., Doğan, S. (2011). A newspecies of Raphignathus Duges and a newly discovered male of $R$. fani Doğan \& Ayy1ldız fromTurkey. International Journal of Acarology, 37, 27-33.
Dönel, G., Doğan, S. (2013). Two new mite species of the genus Raphignathus Dugés (Acari: Raphignathidae) from Turkey. Turkish Journal of Zoology, 37, 179-183.

Fan, Q-H., Yin, X-M. (2000). The genus Raphignathus (Acari: Raphignathidae) from China. Systematic and Applied Acarology, 5, 83-98.

Grandjean, F. (1944). Observations sur les acariens de la famille des Stigmaeidae. Archives des Sciences physiques et naturelles, 26, 103-131.

Kethley, J. (1990). Acarina: Prostigmata (Actinedida). In: Dindal DL, editor. Soil biology guide. New York: John Wiley and Sons, 667-756.

Khanjani, M., Ueckermann, EA. (2003). Two new species of the genus Raphignathus Dugés (Acari: Raphignathidae) from Iran. Acarologia, 43, 299-306.

Koç, K., Ayyıldız, N. (1996). Türkiye faunası için yeni iki Raphignathus Dugés (Acari, Prostigmata, Raphignathidae) türü. Turkish Journal of Zoology, 20, 209214.

Koç, K., Akyol, M. (2004). Favognathus afyonensis sp. nov.with notes on Raphignathus collegiatus Atyeo, Baker et Crossley, 1961 (Acari: Raphignathoidea) from Turkey. Annales Zoologici, 54(2), 475-479.

Koç, K., Akyol, M. (2006). Spil Milli Parkının Rafignatoid (Acari: Raphignathoidea) Akarlarının Sistematik Yönden İncelenmesi. C.B.Ü., Bilimsel Araştırma Projeleri, Manisa, 1- 59 .

Koç, K., Kara, M. (2005). Two new species of Raphignathoidea (Acari: Raphignathidae; Camerobiidae) from Turkey. Acarologia, 45(2-3), 195-202.

Meyer, MKP., Ueckermann, EA. (1989). African Raphignathoidea. Entomology Memoir Department of Agriculture Water Supply Republic of South Africa, 74, 158.

Zaher, MA., Gomaa, EA. (1979). Three new species of the genus Raphignathus in Egypt (Prostigmata: Raphignathidae). Acarologia, 21, 197-203. 